\title{
Improving the compressive strength of lightweight cylindrical concrete column with basalt fiber reinforced polymer acting under imposed load
}

\author{
Paschal C. Chiadighikaobi \\ Peoples' Friendship University of Russia (RUDN University), 6 Miklukho-Maklaya St, Moscow, 117198, Russian Federation \\ passydking2@mail.ru
}

Article history

Received: August 13, 2020

Revised: October 1, 2020

Accepted: October 19, 2020

\begin{abstract}
Relevance. The brittleness of lightweight concrete has developed concern among structural engineers. This concern led to the search on how to improve the strength of lightweight concrete and still retain the weight lightness. Researches are ongoing to solve the strength challenges noticed in lightweight concrete, but at the moment there are few works on solving the issues regarding expanded clay concrete, thus it served as a motivation for studying this issue. The aim of the work is to analyze the effects of basalt fiber polymers on lightweight expanded clay concrete columns acting under imposed loads. Methods. To achieve this process, a total number of nine expanded clay cylindrical concrete columns were experimentalized and analyzed. $1.6 \%$ of dispersed chopped basalt fiber was used in the concrete mixture which serves as reinforcement. Also, basalt fiber mesh was used in the experimental analysis. Results. The expanded clay cylindrical column without basalt fiber polymer withstood strength up to 19.6 tons at 58 minutes, the column with dispersed chopped basalt fiber withstood strength up to 26.67 tons at 61 minutes while the column with dispersed chopped basalt fiber and basalt mesh confinement got destroyed at 29 tons at 64 minutes. The results show that lightweight expanded clay cylindrical columns confined with basalt fiber mesh withstood higher load compared to the columns with just dispersed chopped basalt fiber and without it.
\end{abstract}

Keywords: expanded clay, cylindrical columns, basalt mesh confinement, strength, concrete columns

\section{Повышение прочности на сжатие цилиндрических колонн из легкого бетона под нагрузкой с помощью базальтопластика}

\section{П.Ч. Чиадигхикаоби}

Российский университет дружбы народов, Российская Федерация, 117198, Москва, ул. Миклухо-Маклая, 6 passydking2@mail.ru

\section{История статьи}

Поступила в редакцию: 13 августа 2020 г. Доработана: 1 октября 2020 г.

Принята к публикации: 19 октября 2020 г.

\section{Аннотация}

Актуальность. Проблема хрупкости легкого бетона все больше обращает на себя внимание инженеров-строителей, что привело к поискам способов повышения прочности легкого бетона при сохранении малого веса. Исследования с целью разрешить проблему прочности в легком бетоне продолжаются, однако на настоящий момент существует довольно мало работ по решению задачи прочности керамзитобетона, что послужило мотивацией для изучения данного вопроса. Целью статьи является анализ влияния базальтового волокна на сопротивление легких керамзитобетонных колонн нагрузке.

Paschal C. Chiadighikaobi, Ph.D student of the Department of Civil Engineering of the Engineering Academy; ORCID iD: https://orcid.org/0000-00024699-8166, Scopus ID: 57212346689.

Чиадигхикаоби Паскал Чимеремезе, аспирант департамента строительства Инженерной академии; ORCID iD: https://orcid.org/0000-0002-4699-8166, Scopus ID: 57212346689.

(c) Chiadighikaobi P.C., 2020

(c) () This work is licensed under a Creative Commons Attribution 4.0 International License https://creativecommons.org/licenses/by/4.0/ 


\section{Для цитирования}

Chiadighikaobi P.C. Improving the compressive strength of lightweight cylindrical concrete column with basalt fiber reinforced polymer acting under imposed load // Строительная механика инженерных конструкций и сооружений. 2020. Т. 16. № 5. С. 424-434. http://dx.doi.org/10.22363/1815-5235-2020$16-5-424-434$
Memodbl. Для достижения поставленной цели было испытано и рассчитано девять цилиндрических бетонных колонн из керамзита. В бетонную смесь добавлялось 1,6 \% диспергированного рубленого базальтового волокна, которое служило для армирования бетона. Кроме того, в экспериментах использовалась сетка из базальтового волокна. Результаты. Цилиндрическая колонна из керамзита без базальтового волокна держала нагрузку до 19,6 т в течение 58 мин, колонна с диспергированным рубленым базальтовым волокном - до 26,67 т в течение 61 мин, а колонна с диспергированным рубленым базальтовым волокном, усиленная оболочкой из базальтовой сетки, разрушилась при 29 т через 64 мин. Таким образом, опыты показали, что легкие цилиндрические керамзитобетонные колонны, усиленные сеткой из базальтового волокна, выдерживают более высокие нагрузки по сравнению с колоннами только с диспергированным базальтовым волокном и с колоннами без волокна.

Ключевые слова: цилиндрические колонны, керамзитобетон, усиление базальтовой сеткой, прочность, бетонные колонны

\section{Introduction}

Concrete is the widely used construction material throughout the world; however, it completely losses the load-carrying capacity once cracks/failures are initiated. To overcome these issues, the inclusion of short dispersed fibers in concrete has been practiced and studied by various researchers.

The randomly oriented short fibers control the propagation of microcrack and improve the overall crack resistance of the concrete. Also, the fiber-reinforced concrete (FRC) behaves like a composite material and this behavior is significantly different from the conventional concrete.

Lightweight concrete (LWC) is generally defined as concrete made of ordinary Portland cement (OPC), water, river sand (or lightweight sand), and lightweight coarse aggregates, and its density is typically below to $1950 \mathrm{~kg} / \mathrm{m}^{3}$ [1]. Consider the growing demand, including high-rise buildings, large-span concrete structures, and floating structures, lightweight concrete that is made by diverse types of aggregate has been widely studied and successfully developed and applied over the past two decades [2-6].

LWC offers several advantages, such as saving dead loads for foundations, high strength/weight ratio, and service as ideal filled materials for sandwich structures. Thus, lightweight concrete has many potential applications in the construction industry. Nevertheless, some drawbacks in lightweight concrete's natural mechanical properties have limited applications, especially as load-bearing structural members [3]. At the same mixing ratio and compressive strength, the brittleness of LWC is much higher than normal concrete (NC). Plus, the deformation capacity of lightweight concrete is also poor when compared with NC [7].

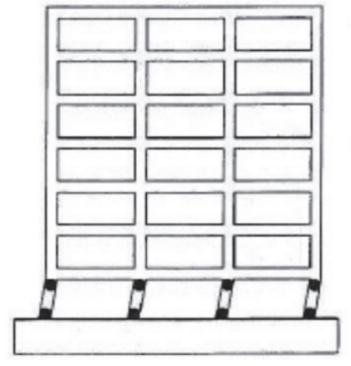

Figure 1. Mechanism of weak column strong beam in a building frame [8]

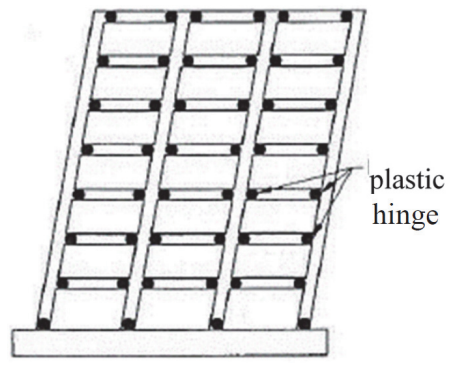

Figure 2. Mechanism of formation of plastic hinge in beams [8]

In many recent earthquakes, it has been observed that buildings with relatively weak columns collapsed in a pancake fashion. This is due to the presence of soft stories and due to the presence of strong beams but comparatively weaker columns (Figure 1). In multistory reinforced concrete buildings, it is desirable to form plastic hinges in beams rather than in columns to dissipate earthquake induced energy by yielding of the beams rather than the columns (Figure 2). The columns are responsible for the overall strength and stability of the structure, during severe seismic jolt. Furthermore, columns are compression members and axial compression reduces the ductility of reinforced concrete columns, thus necessitating more stiff confining reinforcement. Therefore, it is preferable to control inelasticity in columns, to the extent possible, while dissipating most of the energy 
through yielding of the beams as a measure against the total collapse of the structure $[9 ; 10]$. To achieve this "weak beam strong column" objective, the columns of a building can be made stiffer against deformation by wrapping them with fiber-reinforced polymers (FRP). Research work was done to conduct experimental studies of reinforced concrete retaining walls, including considering their reinforcement by inclined reinforcing bars [11]. The results obtained from the research showed the opening of horizontal interblock joints, the formation of inclined cracks emerging from the joints. An increase in the strength of reinforced concrete structures of retaining walls and a decrease in their deformability due to reinforcement by inclined rods in the interblock weld were recorded.

Confinement has been known to add both strength and ductility in the axial direction for concrete column and this idea originally developed back in the 1920s [12]. Numerous conventional techniques, e.g. ferrocement, concreting overlay, grout injection, external reinforcement, post-tensioning, near-surface retrofitting, etc., are available and getting popular for retrofitting of the concrete column. In recent years, the use of fiberreinforced polymers as an external strengthening has gained considerable popularity over conventional strengthening and repair of concrete structures. The FRP composites have been used successfully for rehabilitation and strengthening of existing reinforced concrete elements to meet the higher standard of seismic loading. One popular technique of FRP strengthening is the wrapping of reinforced concrete columns to increase their axial strength, shear strength, and seismic resistance.

Fiber-reinforced polymer composites have become a favorite material of professionals in both engineering and construction due to its advantages. Major ones include lightweight, high strength, and construction convenience [13-19]. FRP composites provide excellent corrosion resistance, which keeps costs down and increases the service life of structural materials [20-29]. The circumferential confinement of FRPs restrains the transverse expansion of concrete; thus, the strength and ductility of FRP-confined concrete are notably enhanced when the concrete is subjected to a triaxial compressive load [30-33]. Therefore, it can be inferred that the problem of high brittleness and the poor ductility of lightweight aggregate concrete can be effectively solved by using FRP confinement. Thus, FRP application can make it an effective method to reduce self-weight in structural design. The advantage of the composite structure is that it can fully use the characteristics of the multi-materials [34-36].

Concrete elements are known for their brittleness therefore the need to strengthen the elements. The column is a very important load-bearing element in structures. Though a lot of researches have been done on the strength improvement of conventional concrete columns, very few researches have been done on the strength of lightweight expanded concrete with or without basalt fiber (BF). Based on the above, this research work has the task to suggest or solve the problem associated with the brittleness of lightweight concrete structural elements.

\section{Materials and methods}

This experimental study of concrete is carried out by using the state standard GOST 10180-2012 [37]. The materials for the lightweight concrete mix and the production of the concrete for this study are listed below for better illustration.

1. Lightweight expanded clay aggregate of 5-8 $\mathrm{mm}$ fraction as coarse aggregate. The lightweight expanded clay was washed to remove the dust in the aggregate. After washing the aggregate, it was spread on the metal surface for 48 hours to dry up. Expanded clay aggregate is a lightweight aggregate from clay. The clay is dried, heated, and burned in rotary kilns at $1100-1300^{\circ} \mathrm{C}$ inhabiting essential properties like lightweight, insulating, strong, non-combustible, and fire-resistant, extremely stable and durable, natural material for sustainable construction, versatility, and high drainage capacity [38-42].

2. Quartz sand of $0.6-1.2 \mathrm{~mm}$ fraction as fine aggregate. A feature of the proposed quartz is the presence of coarse-grained sand, with a large modulus of fineness up to M3,5. Quartz sand has a rounded part with a low content of clay inclusions and inclusions of soft rocks. The resulting quartz sand undergoes additional enrichment and drying. The moisture content is up to $0.2 \%$ [43].

3. Mineral filler Silverbond quartz flour of $50 \mu \mathrm{m}$. Quartz flour is produced by grinding chemically pure, natural quartz sand to a finely divided state. The technology used guarantees the stability of the chemical composition during grinding and allows to get a constant particle size distribution of quartz flour. The crushed quartz flour is represented by rounded particles with uneven, broken edges. Quartz differs from other mineral fillers in hardness, abrasion and chemical resistance, anti-corrosion, and low coefficient of thermal expansion. Quartz is a chemically stable mineral, it is soluble only in hydrofluoric acid. With a low oil absorption and a small surface area of the particles, the use of quartz flour will enable to get a system with a high degree of filling.

4. Binder Holcim Portland cement M500 D20 CEM II 42.5 N. The characteristics of Holcim Portland cement M500 D20 CEM II $42.5 \mathrm{~N}$ : M - brand, 500 is a figure showing the average compressive strength for 28 days in $\mathrm{kg} / \mathrm{cm}^{2}$, 
D - additives, 20 - allowable number of additives in \% (up to 20\%), CEM II - cement containing additives, and the content of additives is 6-20\%, I-type additives, limestone, 42.5-class compressive strength for 28 days, must be at least this value, and B-quick hardening.

5. Organic mineral-based additives: silica fume, and fly ash.

6. Super plasticizing and water-reducing additive Sika Plast concrete.

7. Tap water at room temperature. Generally, water that is suitable for drinking is satisfactory for use in concrete.

For concrete reinforcement, the following materials are needed.

8. Chopped basalt fiber. The length of the chopped basalt fiber used is $20 \mathrm{~mm}$ and the diameter $15 \mu \mathrm{m}$.

9. Basalt mesh. Technical characteristics of the construction grid Ecostroy (basalt mesh):

- tensile strength: longitudinal direction $-50 \mathrm{kn} / \mathrm{m}$, transverse $-50 \mathrm{kn} / \mathrm{m}$;

- the relative elongation (longitudinal, transverse direction) is about $4 \%$;

- the surface density is $200 \mathrm{~g} / \mathrm{m}^{2}$;

- characteristics of the roll: width $-36 \mathrm{~cm}$, length $-50 \mathrm{~m}$;

- cell parameters: $25 \times 25 \mathrm{~mm}$.

The tests will be done on nine expanded clay concrete (ECC) cylindrical columns of four sets of lightweight concrete mixtures. The dimensions of the concrete cylindrical columns are height $300 \mathrm{~mm} \times$ diameter $150 \mathrm{~mm}$. The percentage of BF used as dispersed chopped BF in the ECC is stated in Table in the result section. The three sets of cylindrical concrete mix are:

1) three cylindrical concrete columns without both dispersed chopped basalt fiber and confinement basalt mesh;

2) three cylindrical concrete columns with dispersed chopped basalt fiber without confinement basalt mesh;

3) three cylindrical concrete columns with dispersed chopped basalt fiber and confined with basalt mesh.

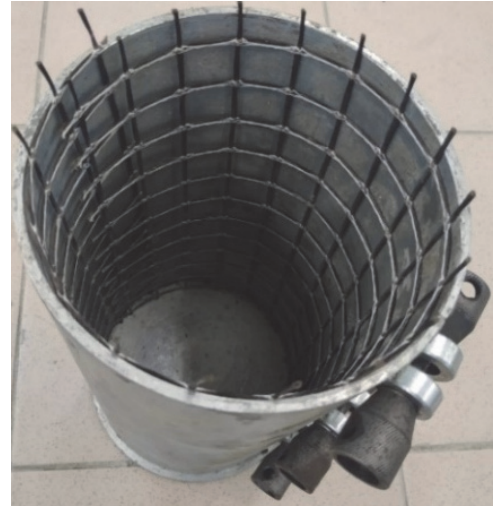

$a$

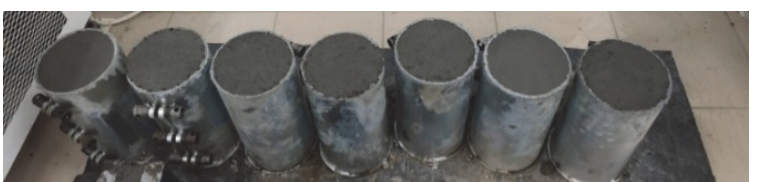

$b$

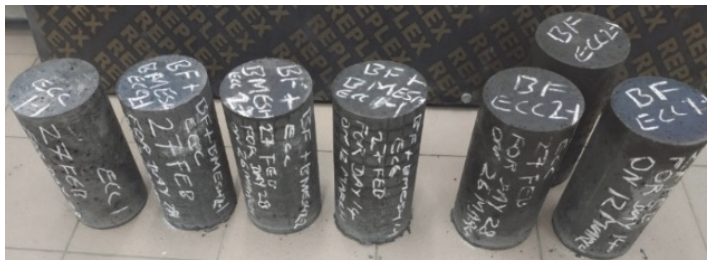

$c$

Figure 3. Process of ECC cylindrical column: $a$ - euro cylinder with basalt mesh for confinement inside; $b$ - ECC in mold; $c$ - ECC cylindrical columns

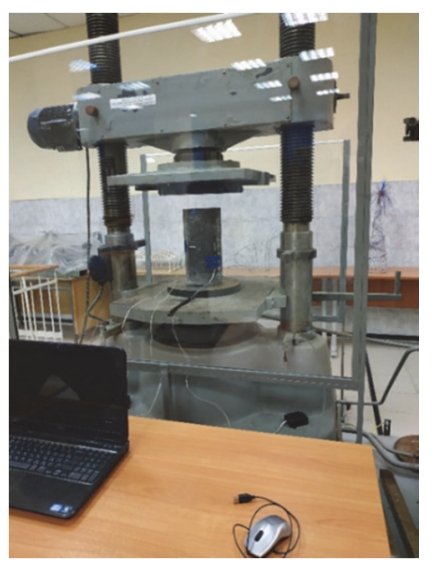

Figure 4. The compressive test is done on hydraulic press PG-100

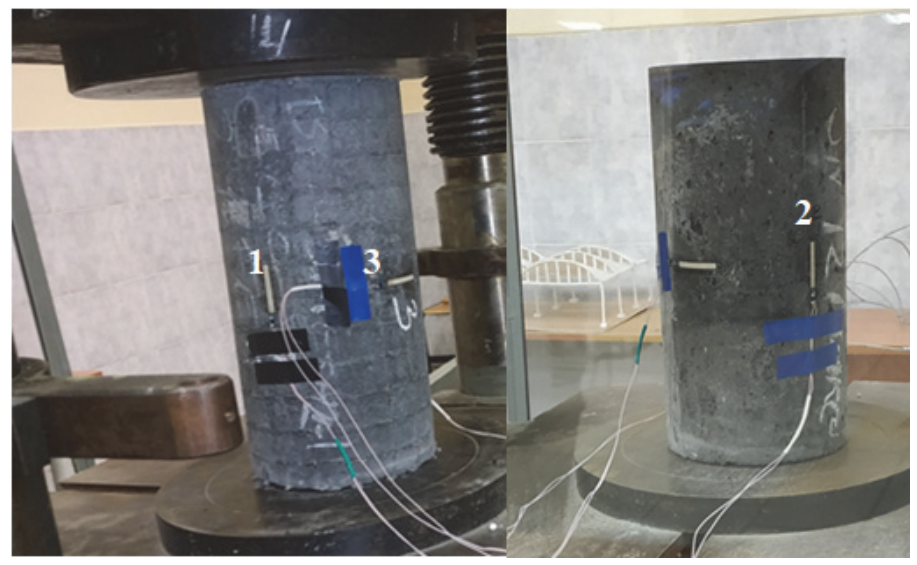

Figure 5. Strain gauge sensor location on ECC cylindrical column 
The columns will be molded in a Euro cylinder of dimensions $\emptyset 150 \mathrm{~mm} \times$ height $300 \mathrm{~mm}$. The concrete columns are molded in Euro cylinder forms according to Eurocode 1 and 2 [44; 45] as shown in Figure 3. After pouring the ECC in cylindrical columns molds, the molds were covered with polytelin and kept at room temperature $(20 \pm 5){ }^{\circ} \mathrm{C}$ and relative air humidity $(95 \pm 5) \%$. On the $76^{\text {th }}$ hour, the ECC columns were removed from the molds and kept in the curing bath till the $28^{\text {th }}$ day then the columns were tested for deformation on a compressive test on a hydraulic press PG-100 (Figure 4).

After the test, a comprehensive strength comparison of the three sets of concrete will be done. From the analysis, the stress deformation and time will be analyzed from the average results of three columns from each of the three sets for comparison. Three strain gauge sensors are clued on the body of the ECC cylindrical column and numbered 1, 2, 3 as shown in Figure 5. Sensors 1 and 2 are for measuring the stress-strain deformation on the vertical zone of the column while sensor 3 is for measuring the horizontal deformation of the column.

\section{Results}

The 1.6\% dispersed chopped basalt fiber used in this research experiment was derived from the compressive test results in Table where ECC cube with 1.6\% BF showed better compressive strength.

Results of the laboratory tests of ECC specimens of $100 \times 100 \times 100 \mathrm{~mm}$ on the compressive strength

\begin{tabular}{cccccc}
\hline \multirow{2}{*}{ Curing period, days } & \multicolumn{5}{c}{ Compressive strength, MPa } \\
\cline { 2 - 5 } & $0 \% B F$ & $0.45 \% B F$ & $0.9 \% B F$ & $1.2 \% B F$ & $1.6 \% B F$ \\
\hline 7 & 14.145 & 15.861 & 18.248 & 20.189 & 23.573 \\
14 & 19.738 & 21.596 & 24.969 & 27.771 & 31.326 \\
28 & 22.524 & 25.123 & 28.497 & 31.926 & 36.235 \\
\hline
\end{tabular}

Figures $6,9,10$, and 11 show the views of the ECC cylindrical columns after they have undergone imposed loads. From the experiments, the ECC cylindrical column could hold imposed loads of up to 19.6 tons. The deformations were measured at a pace of 5 tonnes. The compressive test started at time 18:05 and noticeable deformation started at 18:53 and complete test destruction ended at 19:03. Therefore, it took 58 minutes to achieve the compressive test result at deformation. Figure 9 shows the comparison of the maximum compressive load strength of the columns. Figure 11, it is seen the effect of the load on the strain gage. In Figure 11, the strain gage 1 (in green line graph) sustained from 18:02 - 18:55, strain gage 2 (in red) sustained from 18:02 - 19:02 while strain gage 3 (in blue) sustained from 18:03 - 18:56.

Figures 7, 9, 10, and 12 show the views of the ECC + BF cylindrical columns after undergoing imposed loads. The ECC + BF cylindrical columns could hold imposed loads of up to 26.67 tons. The deformations were measured at a pace of 5 tonnes. The compressive test started at time 16:56 and complete test destruction at 17:57. It took 1 hour and 01 minute for the complete deformation. Figure 12 shows that strain gage 1 (in green line graph) sustained from 16:56 - 17:57, strain gage 2 (in blue) sustained from 16:59 - 17:57 while strain gage 3 (in red) sustained from 16:59 - 17:57.

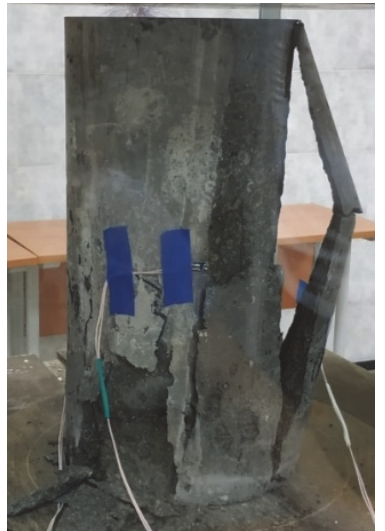

$a$

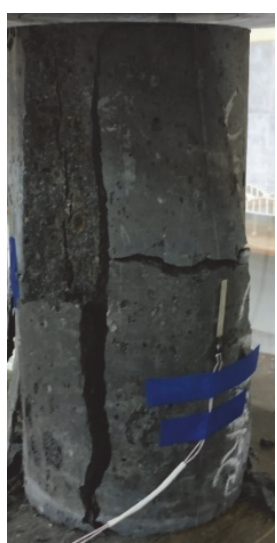

$b$

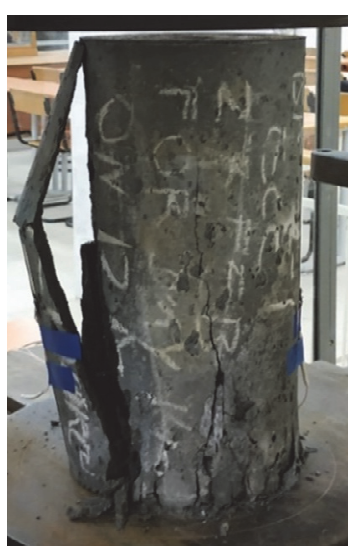

$c$

Figure 6. ECC cylindrical column after imposed loading shows deformation: $a$-at tensile gage $3 ; b$-at tensile gage $1 ; c$-at tensile gage 2 


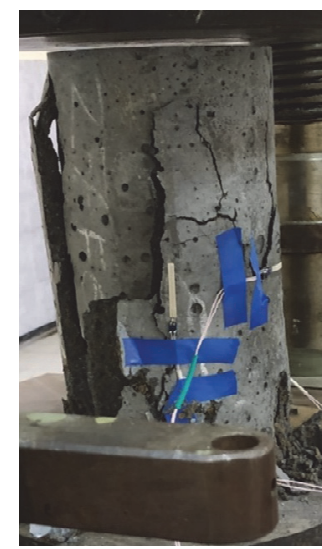

$a$

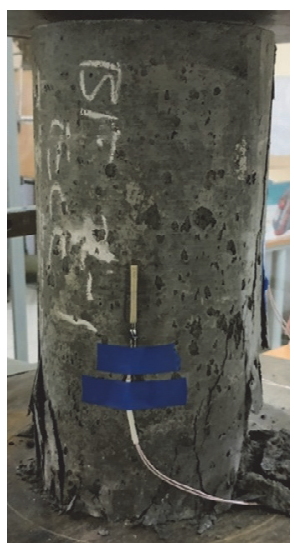

$b$

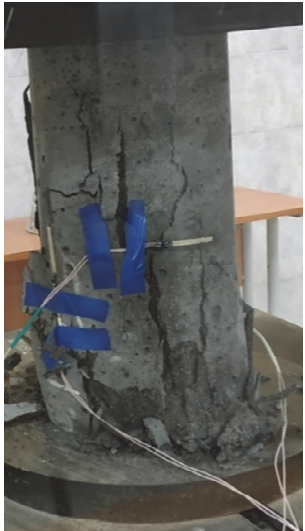

$c$

Figure 7. $\mathrm{ECC}+\mathrm{BF}$ cylindrical column after imposed loading shows deformation: $a-$ at tensile gage $1 ; b-$ at tensile gage $2 ; c-$ at tensile gage 3

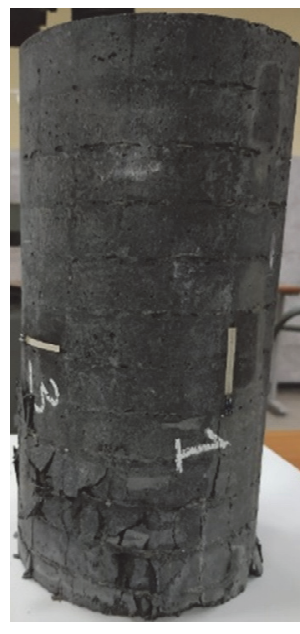

$a$
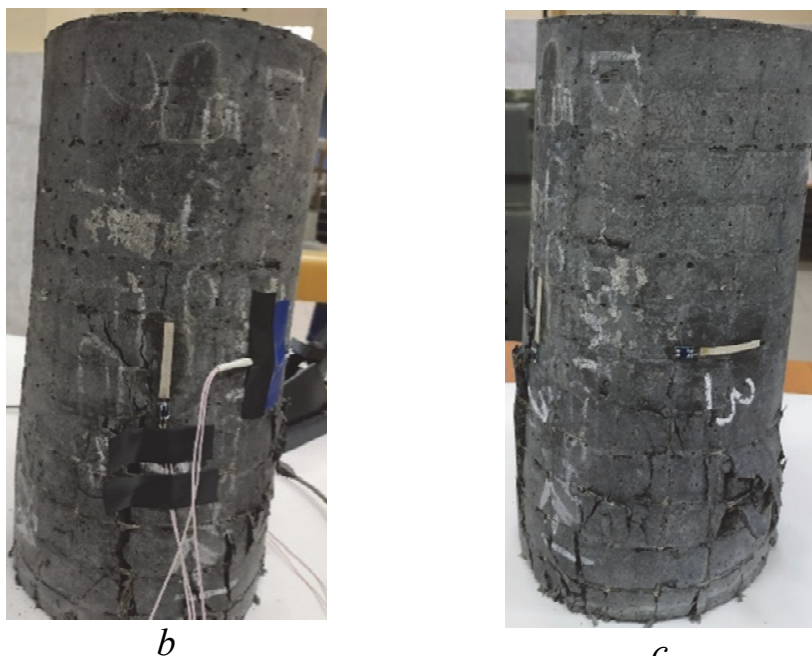

$c$

Figure 8. $\mathrm{ECC}+\mathrm{BF}+$ basalt mesh cylindrical column after imposed loading shows deformation: $a-$ at tensile gage $1 ; b-$ at tensile gage $2 ; c-$ at tensile gage 3

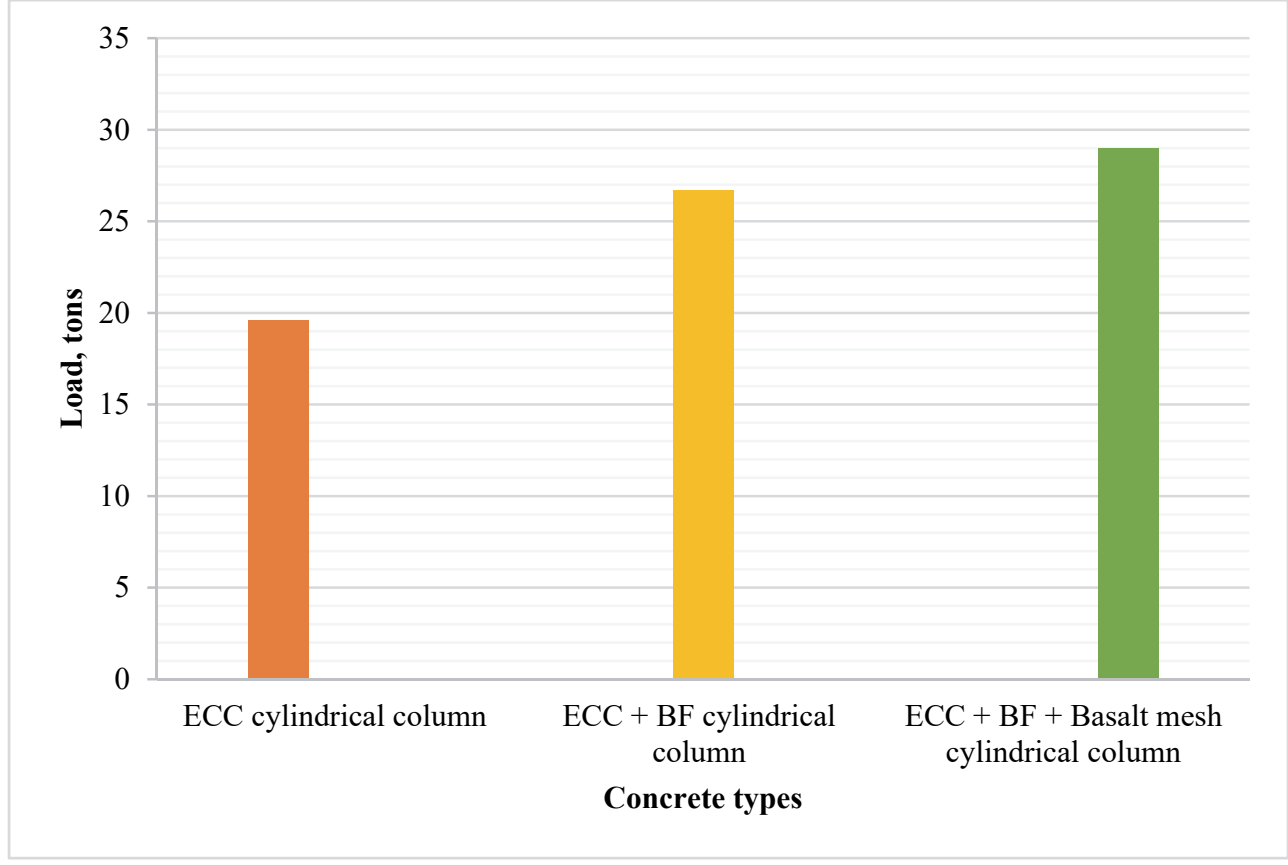

Figure 9. Compressive load diagram of ECC cylindrical columns 


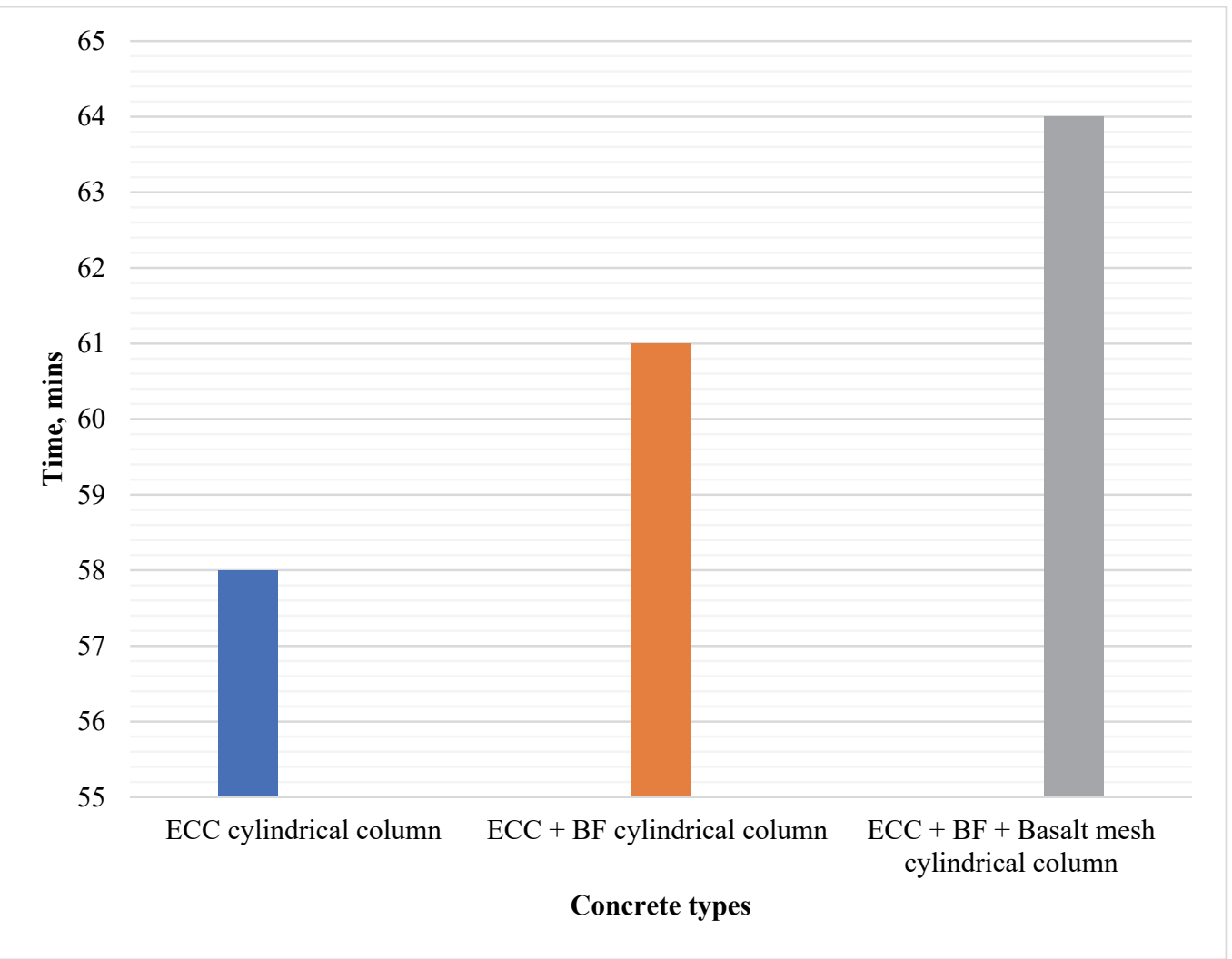

Figure 10. Compressive load time diagram of ECC cylindrical columns

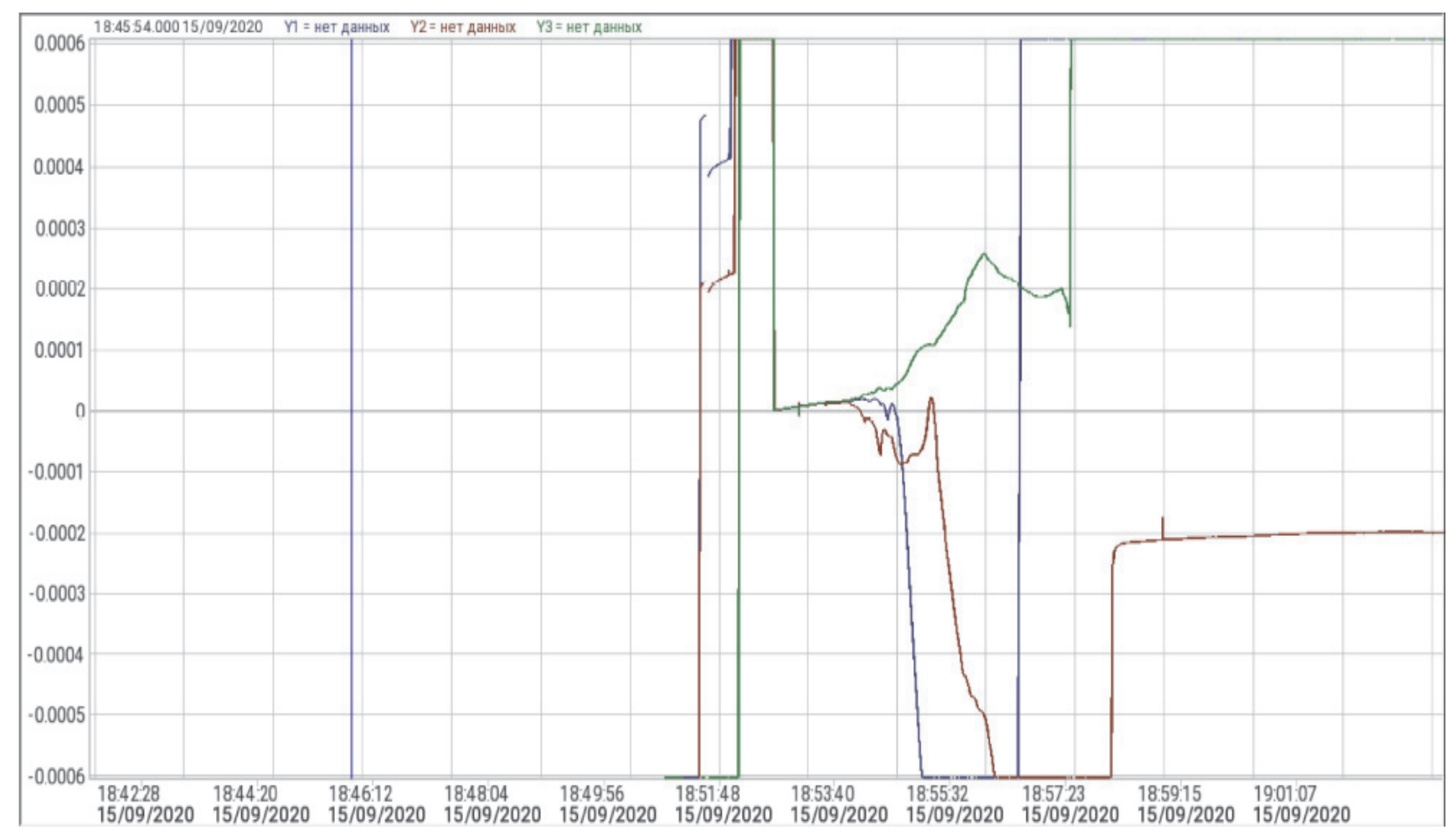

Figure 11. The time-deformation of ECC cylindrical column 


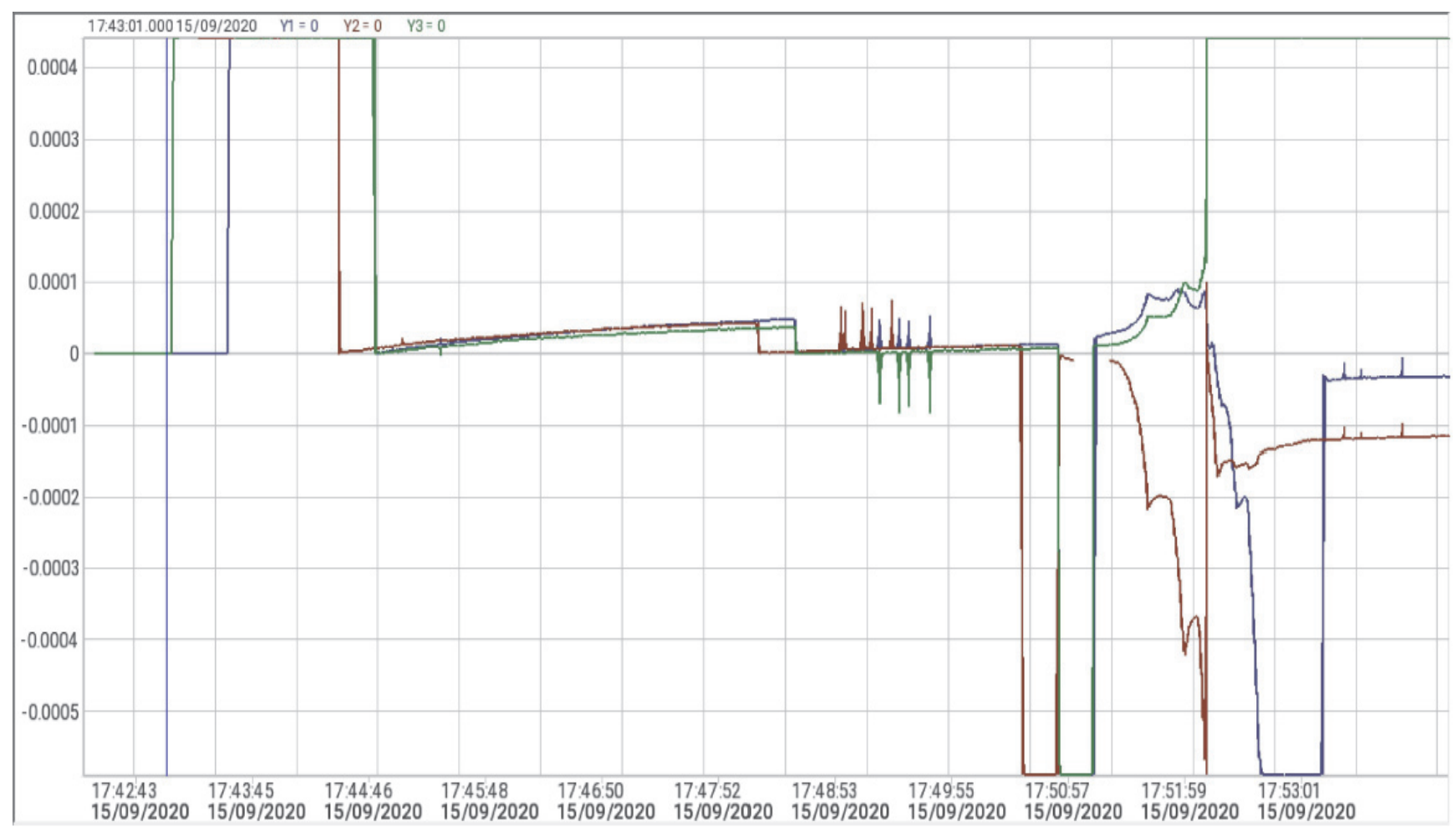

Figure 12. The time-deformation of ECC with BF cylindrical column

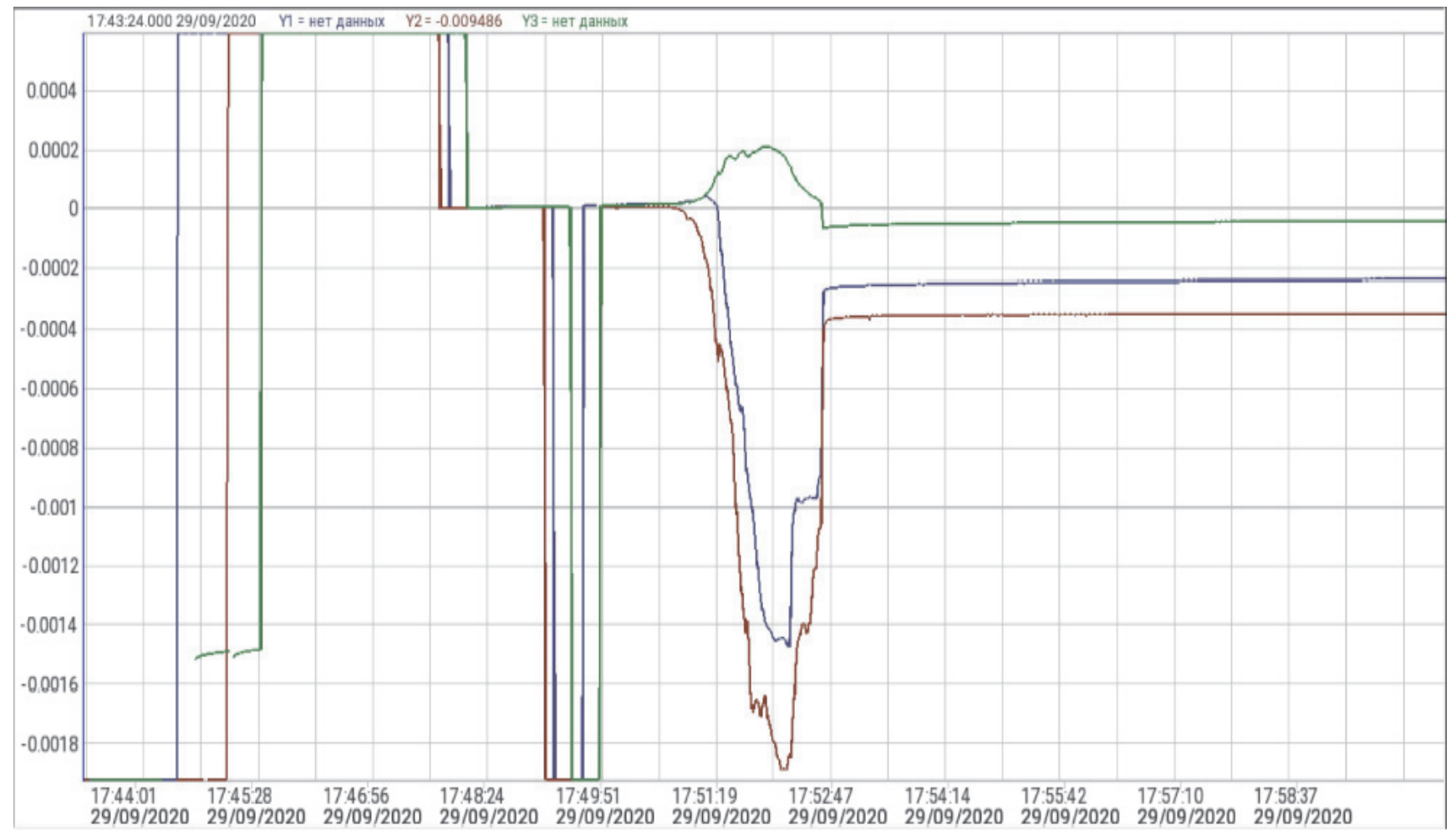

Figure 13. The time-deformation of ECC with both BF and basalt mesh confined cylindrical column 
Figures $8,9,10$, and 13 show the results of $\mathrm{ECC}+\mathrm{BF}+$ Basalt mesh confined cylindrical columns after imposed loads. The ECC $+\mathrm{BF}+$ basalt mesh sustained a load of 29 tons. The compressive test started at time 16:56 and noticeable deformation started at 17:50 and complete test destruction ate 18:00. It took 64 minutes for the complete deformation. Figure 13 shows that strain gage 1 (in green line graph) sustained from 16:59 - 17:59, strain gage 2 (in blue) sustained from 16:59 - 17:59 while strain gage 3 (in red) sustained from 17:00 - 18:00.

\section{Conclusion}

From the experimental results, the following conclusions are made.

1. The addition of basalt fiber in ECC affected the strength of the concrete and the destruction time.

2. The $\mathrm{BF}$ increased the compressive load of the column by $36 \%$ compared to the regular column.

3 . The ECC column with both $\mathrm{BF}$ and basalt mesh improved the compressive strength by $48 \%$ compared to the regular column.

4. A $9 \%$ increase in strength was calculated when comparing the ECC column with BF and basalt mesh to the column with the only BF.

\section{References}

1. JGJ12-2006. Technical specification for lightweight aggregate concrete structures. Beijing: China Engineering and Construction Society Press; 2006.

2. Sohel K.M.A., Liew J.Y.R., Yan J.B., Zhang M.H., Chia K.S. Behavior of steel-concrete-steel sandwich structures with lightweight cement composite and novel shear connectors. Composite Structures. 2012;94:3500-3509. DOI: 10.1016/j.compstruct.2012.05.023.

3. Kong F., Evans R.H. Handbook of Structural Concrete. New York: McGraw-Hill; 1983.

4. Zhou Y., Liu X., Xing F., Cui H., Sui L. Axial compressive behavior of FRP-confined lightweight aggregate concrete: an experimental study and stress-strain relation model. Construction and Building Materials. 2016;119:1-15. DOI: $10.1016 /$ j.conbuildmat.2016.02.180.

5. Wang H.T., Wang L.C. Experimental study on static and dynamic mechanical properties of steel fiber reinforced lightweight aggregate concrete. Construction and Building Materials. 2013;38:1146-1151. DOI: 10.1016/j.conbuildmat.2012.09.016.

6. Huang Z., Liew J.Y.R., Xiong M., Wang J. Structural behaviour of double skin composite system using ultra-lightweight cement composite. Construction and Building Materials. 2015;86:51-63. DOI: 10.1016/j.conbuildmat.2015.03.092.

7. Lim J.C., Ozbakkaloglu T. Stress-strain model for normal-and light-weight concretes under uniaxial and triaxial compression. Construction and Building Materials. 2014;71:492-509. DOI: 10.1016/j.conbuildmat.2014.08.050.

8. Ataur R., Madhobi M., Shantanu G. Experimental behavior of FRP confined concrete cylinder wrapped by two different FRPs. Journal of Materials Science Research. 2018;7(2):1-8.

9. Saatcioglu M. Seismic design. ACI design handbook (SI edition): Design of structural reinforced concrete elements in accordance with the strength design method of ACI318M-05 (chapter 6). Farmington Hills, MI: American Concrete Institute; 2010.

10. Travush V.I., Karpenko N.I., Kolchunov Vl.I., Kaprielov S.S., Demyanov A.I., Bulkin S.A., Moskovtseva V.S. Results of experimental studies of high-strength fiber reinforced concrete beams with round cross-sections under combined bending and torsion. Structural Mechanics of Engineering Constructions and Buildings. 2020;16(4):290-297. http://dx. doi.org/10.22363/1815-5235-2020-16-4-290-297 (In Russ.)

11. Rubin O.D., Lisichkin S.E., Pashchenko F.A. Results of experimental researches of reinforced concrete retaining walls. Structural Mechanics of Engineering Constructions and Buildings. 2020;16(2):152-160. http:// dx.doi.org/ 10.22363/1815-5235-2020-16-2-152-160 (In Russ.)

12. Richart F.E., Brandtzaeg A., Brown, R.L. A study of the failure of concrete under combined compressive stresses. Bulletin No. 185. Champaign, Ill: University of Illinois Engineering Experimental Station; 1928.

13. Li P., Wu Y.F., Zhou Y., Xing F. Cyclic stress-strain model for FRP-confined concrete considering postpeak softening. Composite Structures. 2018;201:902-915. DOI: 10.1016/j.compstruct.2018.06.088.

14. Zhang H., Li H., Corbi I., Corbi O., Wu G., Zhao C., Cao T. AFRP influence on parallel bamboo strand lumber beams. Sensors. 2018;18:2854. DOI: 10.3390/s18092854.

15. Wang H.T., Wu G., Pang Y.Y. Theoretical and numerical study on stress intensity factors for FRPstrengthened steel plates with double-edged cracks. Sensors. 2018;18:2356. DOI: 10.3390/s18072356. 
16. Luo M., Li W., Hei C., Song G. Concrete infill monitoring in concrete-filled FRP tubes using a PZT-based ultrasonic time-of-flight method. Sensors. 2016;16:2083. DOI: 10.3390/s16122083.

17. Yu Q.Q., Wu Y.F. Fatigue strengthening of cracked steel beams with different configurations and materials. Journal of Composite Construction. 2016;21:04016093. DOI: 10.1061/(ASCE)CC.1943-5614.0000750.

18. Yu Q.Q., Wu Y.F. Fatigue durability of cracked steel beams retrofitted with high-strength materials. Construction and Building Materials. 2017;155:1188-1197. DOI: 10.1016/j.conbuildmat.2017.09.051.

19. Teng J.G., Jiang T., Lam L., Luo Y.Z. Refinement of a design-oriented stress-strain model for FRP-confined concrete. Journal of Composite Construction. 2009;13:269-278. DOI: 10.1061/(ASCE)CC.1943-5614.0000012.

20. Kharun M., Koroteev D.D., Dkhar P., Zdero S., Elroba S.M. Physical and mechanical properties of basaltfibered high-strength concrete. Structural Mechanics of Engineering Constructions and Buildings. 2018;14(5):396-403. http://dx.doi.org/10.22363/1815-5235-2018-14-5-396-403 (In Russ.)

21. Chen C., Sui L., Xing F., Li D., Zhou Y., Li P. Predicting bond behavior of HB FRP strengthened concrete structures subjected to different confining effects. Composite Structures. 2018;187:212-225. DOI: 10.1016/ j.compstruct.2017.12.036.

22. Jiang C., Wu Y.F., Jiang J.F. Effect of aggregate size on stress-strain behavior of concrete confined by fiber composites. Composite Structures. 2017;168:851-862. DOI: 10.1016/j.compstruct.2017.02.087.

23. Wu Y.F., Jiang C. Quantification of bond-slip relationship for externally bonded FRP-to-concrete joints. Journal of Composite Construction. 2013;17:673-686. DOI: 10.1061/(ASCE)CC.1943-5614.0000375.

24. Zhou Y., Li M., Sui L., Xing F. Effect of sulfate attack on the stress-strain relationship of FRP-confined concrete. Construction and Building Materials. 2016;110:235-250. DOI: 10.1016/j.conbuildmat.2015.12.038.

25. Sui L., Luo M., Yu K., Xing F., Li P., Zhou Y., Chen C. Effect of engineered cementitious composite on the bond behavior between fiber-reinforced polymer and concrete. Composite Structures. 2018;184:775-788. DOI: 10.1016/j.compstruct.2017.10.050.

26. Dai J.G., Gao W.Y., Teng J.G. Bond-slip model for FRP laminates externally bonded to concrete at elevated temperature. Journal of Composite Construction. 2013;17:217-228. DOI: 10.1061/(ASCE)CC.1943-5614.0000337.

27. Zhang D., Gu X.L., Yu Q.Q., Huang H., Wan B., Jiang C. Fully probabilistic analysis of FRP-to-concrete bonded joints considering model uncertainty. Composite Structures. 2018;185:786-806. DOI: 10.1016/j.compstruct. 2017.11.058.

28. Liu Z., Chen K., Li Z., Jiang X. Crack monitoring method for an FRP-strengthened steel structure based on an antenna sensor. Sensors. 2017;17:2394. DOI: 10.3390/s17102394.

29. Wu Y.F., Jiang C. Effect of load eccentricity on the stress-strain relationship of FRP-confined concrete columns. Composite Structures. 2013;98:228-241. DOI: 10.1016/j.compstruct.2012.11.023.

30. Teng J.G., Huang Y.L., Lam L., Ye L.P. Theoretical model for fiber-reinforced polymer-confined concrete. Journal Composite Construction. 2007;11:201-210. DOI: 10.1061/(ASCE)1090-0268(2007)11:2(201).

31. Jiang J.F., Wu Y.F. Plasticity-based criterion for confinement design of FRP jacketed concrete columns. Material and Structures. 2015;49:2035-2051. DOI: 10.1617/s11527-015-0632-4.

32. Wu Y.F., Jiang J.F. Effective strain of FRP for confined circular concrete columns. Composite Structures. 2013;95:479-491. DOI: 10.1016/j.compstruct.2012.08.021.

33. Jiang J.F., Wu Y.F. Identification of material parameters for Drucker - Prager plasticity model for FRP confined circular concrete columns. International Journal of Solids and Structures. 2012;49:445-456. DOI: 10.1016/ j.ijsolstr.2011.10.002.

34. Valvano S., Carrera E. Multilayered plate elements with node-dependent kinematics for the analysis of composite and sandwich structures. Facta Universitatis. Series: Mechanical Engineering. 2017;15:1-30. DOI: 10.22190/ FUME170315001V.

35. Popov V.L. Analysis of impact on composite structures with the method of dimensionality reduction. Facta Universitatis. Series: Mechanical Engineering. 2015;13:39-46.

36. Rohwer K. Models for intralaminar damage and failure of fiber composites: a review. Facta Universitatis. Series: Mechanical Engineering. 2016;14:1-19.

37. GOST 10180-2012. Betony. Metody opredeleniya prochnosti po kontrol'nym obraztsam [Concretes. Methods for strength determination using reference specimens]. Moscow; 2013. (In Russ.)

38. Slater E., Moni M., Alam M.S. Predicting the shear strength of steel fiber reinforced concrete beams. Construction and Building Materials. 2012;26(1):423-436. https://doi.org/10.1016/j.conbuildmat.2011.06.042

39. Shafigh P., Hassanpour M., Razavi S.V., Kobraei M. An investigation of the flexural behaviour of reinforced lightweight concrete beams. International Journal of Physics and Sciences. 2011;6(10):2414-2421. 
40. Sepehr M.N., Kazemian H., Ghahramani E., Amrane A., Sivasankar V., Zarrabi M. Defluoridation of water via light weight expanded clay aggregate (LECA): adsorbent characterization, competing ions, chemical regeneration, equilibrium, and kinetic modeling. Journal of Taiwan Institute of Chemical Engineers. 2014;45:1821-1834.

41. Md I., Sharmin N.S., Md M., Akhtar U.S.U. Effect of soda lime silica glass waste on the basic properties of clay aggregate. International Journal of Science and Engineering Research. 2016;7(4):149-153.

42. Zendehzaban M., Sharifnia S., Hosseini S.N. Photocatalytic degradation of ammonia by light expanded clay aggregate (LECA)-coating of $\mathrm{TiO}_{2}$ nanoparticles. Korean Journal of Chemical Engineering. 2013;30(3):574-579.

43. Fractionated quartz sand. Available from: http://www.batolit.ru/93 p.shtml (accessed: 06.02.2019).

44. EN 1991-1-1 (2002) (English). Eurocode 1: Actions on structures. Part 1-1: General actions - Densities, self-weight, imposed loads for buildings (Authority: The European Union Per Regulation 305/2011, Directive 98/34/EC, Directive 2004/18/EC).

45. EN 1992-1-1 (2004) (English). Eurocode 2: Design of concrete structures. Part 1-1: General rules and rules for buildings (Authority: The European Union Per Regulation 305/2011, Directive 98/34/EC, Directive 2004/18/EC). 